\title{
Deification, Ethics, and Hermeneutics ${ }^{1}$
}

Derek Brown

Boston College

\section{Derrida: The Inaugural Cut of Death}

My task today is to think Athanasian deification in light of Jacques Derrida's 2003 essay, Rams:

Uninterrupted Dialogue - Between Two Infinities, the Poem. ${ }^{2}$ Immediately, such a dialogue faces challenges. Derrida did not write about Athanasius. Athanasius, obviously, did not write about Derrida. The "dialogue," then, is imaginary. It is an imagined dialogue between ancient and postmodern, between Greek and French, and between Christian and atheist. And so I will be honest, and admit that this imaging is a tactic, contributing to a larger strategy: I want to deploy and exploit Derrida's thought in such a way as to challenge ontologizing, or "physicalist," readings of Athanasius. I want to join the current effort to free Athanasius from crude “Alexandrian" categorization. ${ }^{3}$ In the final analysis, I claim that we participate in the trinity, and deification is always participation, when we carry the risen Christ in ourselves-who is, of course, also carrying us. Admittedly, I don't have time for all of this. And so I will trust that the audience has some familiarity with Athanasius's account, and will spend most of my time explicating Derrida's thought. I hope that, as I do so, your own understanding of Athanasian soteriology is working. At the very end, I will offer my direct, brief thoughts on this relationship.

\footnotetext{
${ }^{1}$ This paper served as a point of departure for a larger piece, "Athanasius, Derrida, and the Carrying of Deification," which appears in Phronema 32.1 (2017).

22 Derrida, Jacques. Beliers. Le dialogue ininterromu: Entre deux infinis, le poeme (Galilee, 2003). References to the text will use the Dutoit and Romanski translation: "Rams: Uninterrupted Dialogue-Between Two infinites, the Poem." From, Sovereignties in Question: The Poetics of Paul Celan, trans. by T. Dutoit and P. Romanski (Fordham University Press, 2005).

${ }^{3}$ Dragas, George Dion. St. Athanasius of Alexandria: Original Research and New Perspectives. (Orthodox Research Institute, 2005), pgs 2-23
} 
Jacques Derrida's "Rams" was originally published, in French, in 2003. The essay is, in one sense, a reflection on the death of Hans-Georg Gadamer, Derrida's friend. In another sense, the essay is meant as a meditation on the relationship between Gadamerian hermeneutics and Derridean deconstruction—or, as he had taken to calling it by this time, "disseminal reading." It would be an imposition of force to separate these two senses of the essay: Through the essay's breathtaking 30 pages, Derrida illustrates the ways in which death both makes possible the potential of any hermeneutic reading and forbids the possibility of any exhaustive hermeneutic. It is my belief, fostered in large part by the performative force of Rams, that contemporary Catholic theology too quickly accepts the necessity of a hermeneutic register. The objects of theology resist interpretation - they do not lend themselves to it. And to the extent that all language is a play of presence and absence, and requires the absence of the other, we should be more concerned than we are with what and who are absent in our readings; with what and who we employ to do the work of serving as our hidden hermeneutical foundations. The labor of theology should neither exploit nor hide the absent, the voiceless, the worthless, the chaotic, and the other. I am not convinced that any hermeneutic strategy is capable of this. But I digress, back to Derrida.

The first section of Derrida's essay offers some initial thoughts on the relationship between death, friendship, mourning, and melancholy. Working in a Freudian register against which the end of the essay will resist, Derrida first complicates the temporality of mourning. Starting with the example of friendship, we recognize the certainty of death: "A fatal and inflexible law: one of two friends will always see the other die. The dialogue, virtual though it

\footnotetext{
${ }^{4}$ The most helpful report on the difference between Derridean deconstruction and Gadamerian hermeneutics remains Ernst Behler's "Deconstruction versus Hermeneutics: Derrida and Gadamer on Text and Interpretation,” Southern Humanities Review 21.3 (1987).
} 
may be, will forever be wounded by an ultimate interruption." ${ }^{5}$ Our friendship is always marked by the futural trace of death. And so my mourning for you does not wait for your death. ${ }^{6}$ Instead, I internalize this mourning as melancholy. In this way, death is an interruption that precedes itself: our friendship is always already interrupted by knowing that one of us will be without the other. Entering into friendship, then, is entering into this certainty of death. ${ }^{7}$

In this way, it is better to speak of an "inaugural cut" than it is an interruption of the friendship. ${ }^{8}$ Right from the beginning, our friendship is cut open by the "ineffaceable wound" of death. The offer of friendship is an offer of hospitality, and here we must hear the "hospital" in "hospitality." You or I will first die, and this will hurt—indeed, it already does. And yet, we carry the relationship on. The relationship is this carrying, and this is a carrying made possible by the wound itself. The wound, a "wound whose lips will never close," is the openness in which you can be carried, and in which you can carry me. The lips of this wound will never close because death cannot be saturated. Our friendship is always marked by the unsaturated groundlessness of death, and it is because of this silent and groundless wound that anything like an infinite dialogue, to return to Gadamer, is possible. That is, it is only because of radical finitude — because of the certainty of death and its inaugural cut—that anything like infinitude is possible. My cogito is "a cogito of adieu" and my salut is always "without return," but in this

\footnotetext{
${ }_{6}^{5}$ Rams, 139

6 "Mourning no longer waits." Rams, 140

${ }^{7}$ Derrida claims that death is not just the death of the other, but, indeed, "the end of the world." The point is crucial for the text, and I develop the importance of this apocalyptic trait in the aforementioned Phronema article. Yet, because of time constraints, I cannot address the end of the world here today. I think, though, that this is okay. For whereas the deconstructed subject is never without world, so too the deconstructed world is never without friends, without persons. My speaking of persons and friends here-leaving the world in the margins - does not ignore this element of Derrida's text, but neither does it bring it to the fore (can the world, especially the loss of the world, ever be brought to the fore?).

${ }^{8}$ Rams, 152
} 
way they are never closed off or finished. ${ }^{9}$ The mouth which speaks this wound will never close. Death is both that which requires the survivor to carry the deceased and that which allows the survivor to do so. And so attempts to find identity between, say, being and consciousness, attempts to extol the mystery and experience of blissful consciousness, must confront, Derrida says, that this consciousness is never present to itself, is always wounded, is never itself interpretable, and is, at bottom, parallax and suffering, an experience not of divine presence and the living God, but of adieu.

I digress. This is the point in the text where the difference between the disseminal and the hermeneutic becomes legible. The dialogue of friendship must remain a dialogue, and not an appropriation:

It's a question of carrying without appropriating to oneself. To carry now no longer has the meaning of to comprise, to include, to comprehend in the self, but rather to carry oneself toward the infinite inappropriability of the other, toward the encounter with its absolute transcendence in the very inside of me, that is to say, in me outside of me. ${ }^{10}$

This obligation to carry prioritizes dialogue over anything like an internal monologue. The monological subject is dislocated in favor of a carrying subject: "I am alone to the other, alone to him and for him. I am left with the immediacy of the abyss that engages me on behalf of the other wherever the 'I must' - 'I must carry you'-forever prevails over the 'I am.' Before I am, I carry. Before being me, I carry the other."11 This "dialogue," though, is not like a conversation between two living persons. The carried other, who is internal to myself, is a dead other, who cannot speak. It is the abyss that engages the survivor on behalf of the deceased, it is not the

\footnotetext{
${ }^{9}$ Rams, 140

${ }^{10}$ Rams, 161. I have altered Dutoit's translation, which might be a typeset error: “...but rather to carry oneself for the bear oneself toward the infinite inappropriability of the other." In place of the italics, Derrida simply has, "se porter vers." On the phenomenon of unintelligible translations of Derrida, see: Geofrrey Bennington, “Embarrassing Ourselves,” LA Review of Books, 2016.

${ }^{11}$ Rams, 162
} 
deceased herself who works through, speaks to, or engages the survivor. The deceased is gone. Actually absent. The survivor carries the deceased, as she always has, but there the inaugural cut is filled only with the abyss. For, if the cut was healed, if the lips of the wound were closed, then the survivor could not carry the other. And now, with this understanding of death as constitutive of relationship —at least this sort of intimate relationship — we can briefly turn to Athanasius's account of the soteriological impact of Christ's death, of our relationship with Christ.

Quickly, Athanasius's soteriological narrative goes something like this: In the beginning, all creation was created of nothing. The act of creation is not a bridge that crosses us over the threshold of nothingness. Rather, creation remains of nothing, nothingness is constitutive of creation, and so creatures "naturally" return to nothing. It is only by God's grace, by the free impress of God's Image onto humanity, that humans have the ability to share in eternal life. For Athanasius, then, "deification" is first and foremost grace, and is realized by, he says, the “expression" of God's Image. When we express God's Image, we live, and so overcome our constitutive nothingness.

Sin, then, is the turn from God's saving image toward lesser, corruptible things. In $O n$ The Incarnation, these lesser things are typically sensorial things. In Against the Heathens they are idolatrous practices. The Life of St Anthony tells us that Anthony moves to the desert to free himself from these corruptible things. The Letter to Marcellinus tells us that the psalms are places where we can turn to God, and that the reading and singing of psalms is the way of expressing God's image. The theme recurs. Regardless, Christ's saving function, then, is to "cleave" the Image — which is Christ - to the very nothingness of creation. Christ, for Athanasius, is both the granter and, importantly, receiver of salvation: Christ is a creature of nothingness wherein the living Image never ceases expression. Our constitutive nothingness is 
revealed, in Christ, as what it is: nothing. Athanasius is fond of a monarchy metaphor: Christ is the legitimate king whose presence reveals the nothingness to be a false tyrant, and so saves us, his subjects and disciples, from the tyrant's reign.

This, more or less, is the extent of the ontological reading. It is the Incarnation that saves. But this is not the whole of Athanasius's argument. This becomes clear in his festal epistles, and their discussion of the Eucharist and fasting: "Because He was sacrificed, let each of us feed upon Him, and with alacrity and diligence partake of His sustenance; since He is given to all without grudging, and is in every one a well of water flowing to everlasting life.",12 Athanasius's emphasis is not on Christ's incorporation of humanity - contra ontologists - but is on humanity's incorporation of Christ. The salvific move cannot only be Christ's ontological correction of human corruption, because this correction was already made in the beginning, when we were graced with the life-sustaining Image. Indeed, using Derridean categories, we can say that at no time were we alone. The original impress of the Image was God's entering into relationship with, and offering of hospitality to, mortality. In this, God promised to carry us. We were mortal, and so needed to be carried in order to share in God's being. For Athanasius, God has never stopped carrying us, but we have turned from God's welcoming arms. The death of Christ is the sacrifice that once again offers us sustenance, after we have rejected God's carrying. The salvific offer, then, must not be Christ's incorporation of us, but of our re-incorporation of Christ, the acceptance and carrying of His food and His victory over death. The pertinent associative cluster, the operative language game, then, is not hermeneutic - it's a language of hospitality, of offering, of carrying, of ethics.

\footnotetext{
${ }^{12}$ FE, letter 11, pg 83
} 
Far from an imposition of literary theory onto Athanasius, I believe that this mutual carrying is the most faithful reading of Athanasius, and perhaps the only way to make sense of Athanasius's account of Christ's death in soteriology. Christ's death, for Athanasius, is meant as an offer to all: "How could He have called us if He had not been crucified, for it is only on the cross that a man dies with arms outstretched? Here, again, we see the fitness of His death and of those outstretched arms: it was that He might draw His ancient people with the one and the Gentiles with the other, and join both together in Himself." ${ }^{, 13}$ And yet, precisely as crucified and as offered to all, any relationship with the Image, with Christ, is a relationship with the dead. In this way, a Derridean reading is helpful: we must carry Christ. In his death, Christ made himself available to all and for all, and trusted himself into the carrying arms of the disciples. But also in this way, relationship with God is more radical than Derridean friendship: For Derrida, we know our friend will die; for Athanasius, for us, Christ already has. Moreover, it is precisely because Christ has died, precisely that we are cut, that we can feast on his sustaining life, and that all have been offered a share in this meal. The ultimate difference between Athanasian soteriology and Derridean carrying, then, is not the role of death in life, but is the carrying of deification. Derrida's inaugural cut carried the other, but only an abyssal trace of the other. The cut wrought by Christ's death allows us to consume his life-granting bread. Speaking of the singularity of a poem, Derrida says, "we hear it entrust itself to the care of the other, to our care, and put itself secretly within the range of the other." ${ }^{\text {14 }}$ This, I say, is what we hear in Christ's cry on the cross: we hear his putting himself in our care, to be carried, so that he can again carry us.

\footnotetext{
${ }^{13} \mathrm{DI}, 35$

${ }^{14}$ Rams, 159
} 